\title{
ECONOMY OF HELLENISTIC, ROMAN AND EARLY BYZANTINE SETTLEMENT IN JIYEH (PORPHYREON), LEBANON
}

\begin{abstract}
Regular excavations of the ancient settlement in Jiyeh on the Phoenician coast, carried out by the Polish-Lebanese mission since 2008, as well as results of some earlier archaeological investigations there, allowed to discuss various aspects of economic activity of the local population in the Hellenistic, Roman and Early Byzantine times. The obtained materials justify putting forward several hypotheses concerning the agriculture, crafts and trade carried out by the inhabitants of the settlement. It seems that olive oil and wine, together with the locally manufactured coarse pottery vessels and other products, sold within the territory of the neighbouring towns (Sidon and Berytus), could have been the main source of profit allowing the inhabitants to purchase imported goods, such as fine pottery and marbles coming from different parts of the Mediterranean. Moreover, the settlement in Jiyeh, due to its favourable geographical location, may have played an important intermediary role in the trade exchange between the villages located to the east, on the slopes of Mount Lebanon, and urban centres along the Mediterranean coastline.
\end{abstract}

The settlement in Jiyeh, tentatively identified as ancient Porphyreon, ${ }^{1}$ is located on the Phoenician coast, at the foot of Mount Lebanon, at a distance of ca. $25 \mathrm{~km}$ from Beirut (ancient Berytus) and ca. $12 \mathrm{~km}$ from Saida (ancient Sidon) (Fig. 1). The site has been excavated at intervals since 1997 by the Polish-Lebanese archaeological mission directed by Tomasz Waliszewski as part of a larger project which aims at studying the settlement history in the hinterland between Sidon and Berytus. ${ }^{2}$ The research is exceptional for Lebanon where for many years mainly the principal ancient urban centres were intensively investigated, and only rarely there have been attempts at determining their rural hinterlands. The aim of this paper is to reconstruct the basic elements of the economy of the investi-

\footnotetext{
1 Cf. E. LIPIŃSKI, Itineraria Phoenicia (OLA 127, Studia Phoenicia XVIII), Leuven-Paris-Dudley 2004, 20-21, 289 (see Abbreviations, p. 44).

2 On the archaeological research in the area of Jiyeh, see T. WALISZEWSKI, Introduction, in: WALISZEWSKI et al. 2006, $7-9$. On other archaeological research carried out as part of this project, cf. WALISZEWSKI et al. 2002, 5-105; K. JAKUBIAK, Eshmoun Valley preliminary report after the third season of the Polish-Lebanese survey, PAM 20, 2011, 295-301, with further references.
} (c) IAE PAN and Mariusz Gwiazda, 2014 gated settlement from the Hellenistic until the Early Byzantine period. Since the research is now in progress, and the archaeological material has not been fully analysed, the conclusions presented below are of a tentative character. They are meant as a basis for further investigations focused on obtaining a more complete picture of the transformations that occurred in the discussed region.

The archaeological materials discussed below were obtained mainly during the Polish-Lebanese excavations in 1997, 2004 and 2008-12, the earlier Lebanese excavations carried out in 1975 by Roger Saidah, and the rescue operation aimed at saving mosaic floors exposed in the Christian basilica by the local population in $1988 .{ }^{3}$ Ancient written sources are of secondary importance for the discussion as

\footnotetext{
3 R. SAIDAH, Porphyréon du Liban: une Pompéi byzantine enfoui sous le sable, Archéologia 104, 1977, 38-43. The objects from R. Saidah's excavations are currently stored in the Beirut National Museum. Mosaics and other objects from the rescue excavations in 1988 were moved to the Beit ed-Dine Palace Museum. Most of the materials from the recent Polish-Lebanese excavations are stored in the excavation houses at Jiyeh and Chhim, while some selected finds were handed over to the Beirut National Museum.
} 


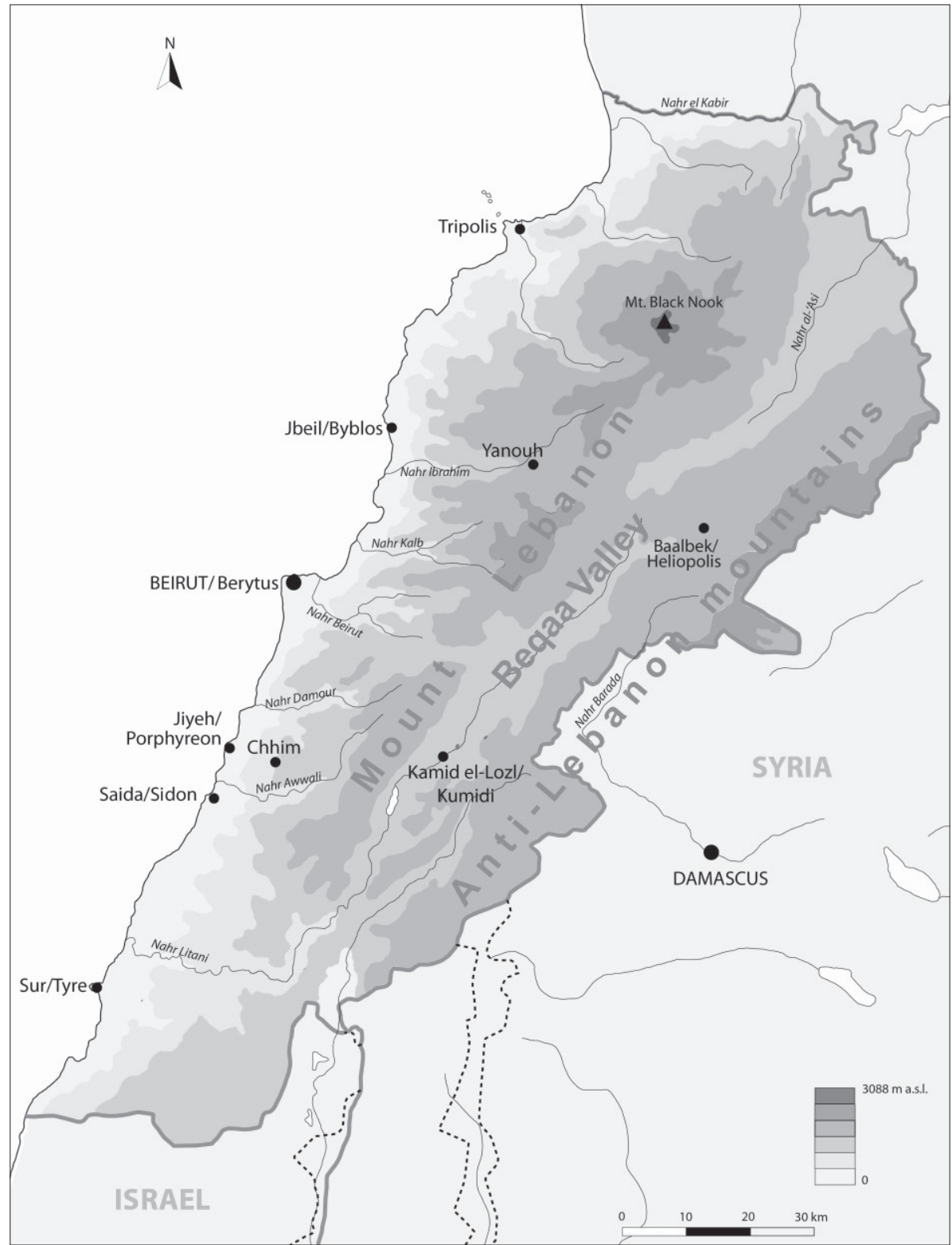

Fig. 1. Map of Lebanon (by U. Wicenciak)

they provide only fragmentary information on the site. $^{4}$

Although the earliest phase of the settlement's occupation goes back to the late Bronze Age, ${ }^{5}$ the majority of archaeological evidence is dated from the Persian period until the Early Byzantine times, with a clear predominance of the Roman and later architectural remains. This is due to the fact that subsequent structures were erected on the earlier

4 Cf. LIPIŃSKI, op. cit. (n. 1), 20-21.

5 T. WALisZewski, K. JuCHNIEWICZ, M. GWIAZDA, Preliminary report on the 2008 and 2009 excavation seasons at Jiyeh (Porphyreon), PAM 21, 2012, 431-437; U. WICENCIAK, A local Hellenistic "Phoenician"-type amphora and other pottery from excavations in Jiyeh (Porphyreon)(Season 2008-2009), PAM 21, 2012, 447-449. ones. As a result, the earliest remains are in some places covered by cultural layers and structures the total thickness of which amounts to ca. $4 \mathrm{~m}$, and thus they can only be reached by trial pits. The settlement was abandoned during the 7th century AD, as indicated by coins, ceramic tableware and other archaeological materials. ${ }^{6}$

Today, the most intensively excavated part of the settlement is located on the plot belonging to the Lebanese Ministry of Culture (Fig. 2). In the eastern part of this area there are relatively well preserved remains of some residential buildings which can be

6 SAIDAH, op. cit. (n. 3), 40, 43. Information on the dating of the fine pottery was obtained from K. Domżalski who is responsible for publishing these finds from Jiyeh. 


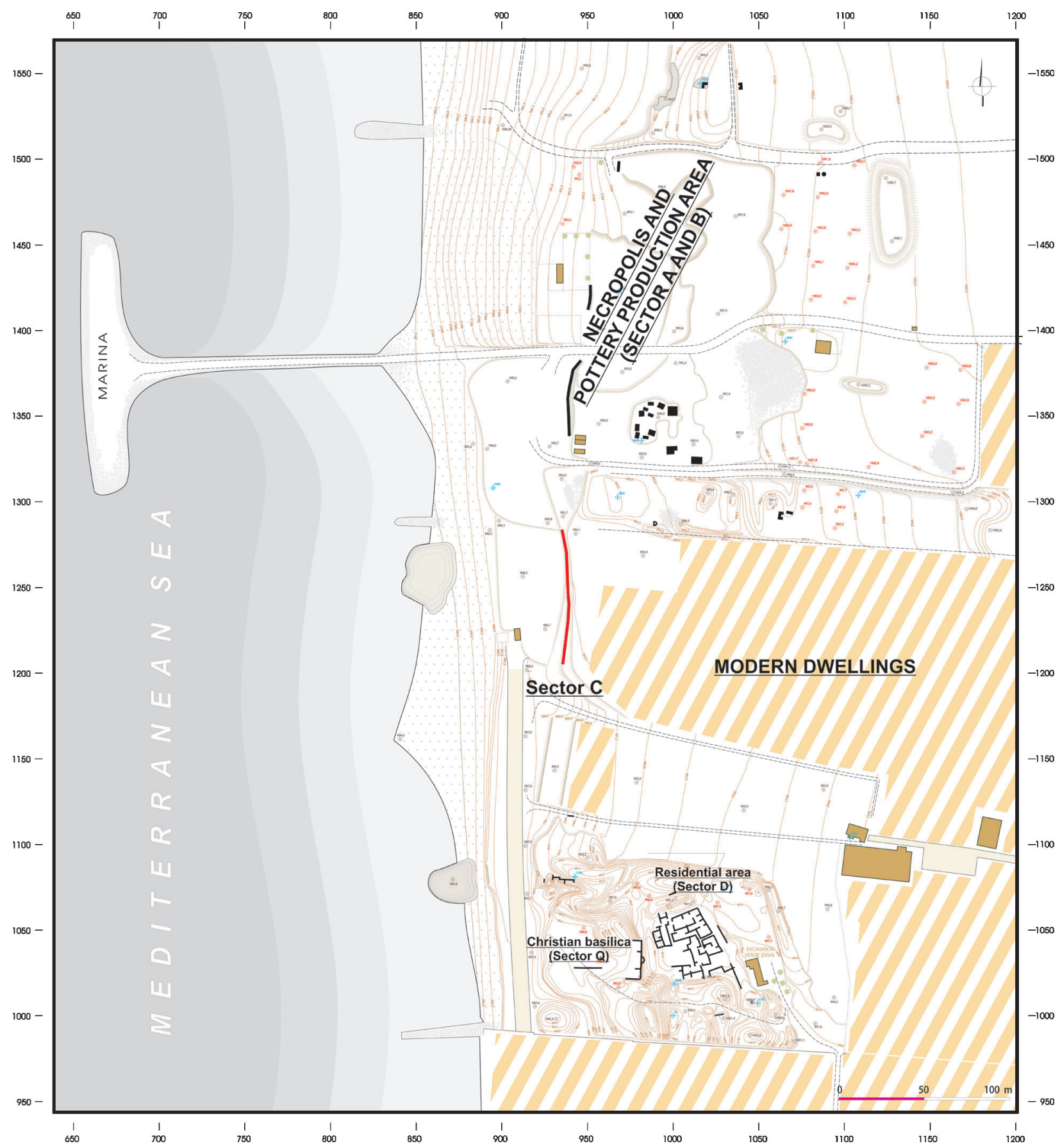

Fig. 2. Ancient settlement in Jiyeh with excavated sectors (by M. Puszkarski)

dated to the 4 th - mid-7th century (Sector D), and in its western part there is a large Christian basilica erected in the 5 th or 6 th century, with unidentified buildings adjacent from the north and south, covered by dunes (Sector Q). Ca. $130 \mathrm{~m}$ to the north of the settlement there was a potters' quarter active between the 2 nd century BC and the 1 st century AD (Sector B). Next to it, a necropolis with Hellenistic, Early Roman and Early Byzantine graves was situated (Sector A). Currently, this part of the site is largely damaged or inaccessible due to the fact that a holiday resort has been built there since 2004 .
Some traces of settlement between the residential quarter with the adjacent basilica and the necropolis have been discovered as well. During the construction work carried out by the landowner in 1998, remains of a house were uncovered, with a mosaic featuring a Nilotic scene, dated on the basis of its iconography to the late 5 th -6 th century. ${ }^{7}$ Moreover, in 2005 an $84 \mathrm{~m}$ long section along the western edge

\footnotetext{
7 R. ORTALI-TARAZI, T. WALISZEWSKI, La mosaïque du Nil
} découverte à Jiyé, BAAL 4, 2000, 165-177. 


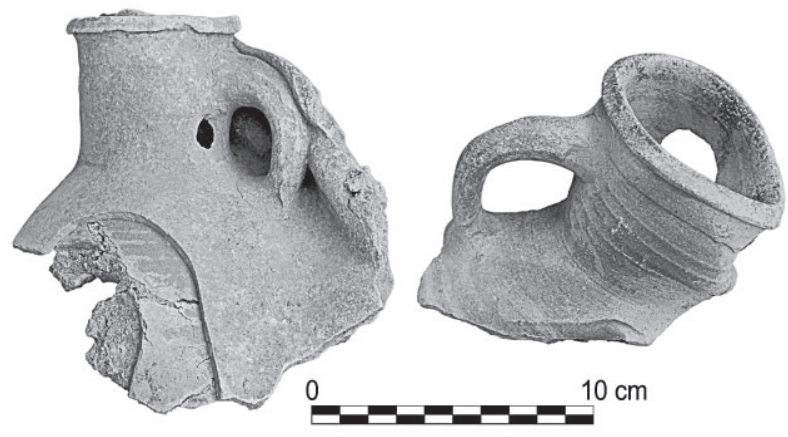

Fig. 3. Late Hellenistic pottery wasters (by M. Kisielewicz)

of this area (Sector C) was uncovered during another construction works, revealing remains of houses and layers containing materials dated from the Persian times until the Early Byzantine period. ${ }^{8}$ All these structural remains and features indicate that the settlement was rather large, with a surface of at least 77,000 sq.m. As the area beyond its southern and eastern borders is covered by modern buildings, it is difficult to establish the extension of the ancient settlement there. ${ }^{9}$

In $2008-12$, only a small part of the settlement has been investigated stratigraphically. The best preserved architectural remains were uncovered in 1975 by R. Saidah, and a large part of the archaeological materials used in the discussion below comes from heaps formed as a result of these excavation works, as well as the robbery which followed later. Some of these secondary deposits were finally removed by the Polish-Lebanese mission. They contained mixed materials which, however, provide important data on local crafts, trade exchange, agriculture and fishing.

The most impressive craft activity of the settlement in the discussed periods is production of ceramic objects. Although no pottery kilns have been found to date, this type of production is confirmed by the finds of coarse pottery wasters (Fig. 3) and plaster moulds for manufacturing terracotta oil lamps. The finds of the pottery wasters are concentrated in two parts of the site (Sector B and C). The first evidence was discovered during the rescue excavations in 2004-05, connected with the construction of the above mentioned holiday resort to the north of the settlement (Sector B), where large amounts of broken

8 U. WiCEnCIAK, M. EL TAYEB, Section C-Jiyeh, 2005 season, in: WALISZEWSKI et al. 2006, 67-79.

9 The second largest settlement in the vicinity of Jiyeh, dated mainly to the Roman and Early Byzantine periods, with a total surface of 27,000 sq.m, is located at Chhim, ca. $6 \mathrm{~km}$ to the east. This mountain village, consisting of houses, olive oil and wine presses, a pagan temple, a Christian basilica and a necropolis, was investigated in 1996-2009 by the Polish-LebaneseFrench archaeological mission; cf. WALISZEWSKI et al. 2002. and deformed pottery were found, as well as traces of ash and burning, probably left by their firing in kilns. The available dating material (mainly some imported fine pottery fragments) allowed to determine that the coarse ware vessels, such as cooking pots (the most common form), casseroles, bowls, pans, pot stands, jugs, juglets, flasks and amphorae, were produced there between the 2nd century BC and the 1 st century AD. The scarcity of finds connected with domestic activities, such as animal bones, indicates that the place was used exclusively for production purposes. The structures used by the potters were most likely destroyed in a later period by enlargement of the necropolis which was located nearby. ${ }^{10}$

Basing on the form and fabric of Late Hellenistic and Early Roman amphorae and kitchen vessels found in the test trenches in the residential quarter (Sector D) and in the potters' quarter (Sector B), U. Wicenciak suggested that there was a relationship between the workshop in Jiyeh and those in Berytus and Sidon. However, it is not clear whether the vessels produced in Jiyeh would be used in Berytus, or imitations of forms from Berytus were produced in Jiyeh for local needs. ${ }^{11}$ The distribution of Hellenistic and Early Roman amphorae produced in Berytus and Jiyeh is very limited and the finds come mainly from the production centres themselves. A few examples are also known from Sidon, ${ }^{12}$ Chhim, ${ }^{13}$ and

10 K. DOMŻALSKI et al., Late Hellenistic and Early Roman Pottery Production Center at Jiyeh: Rescue Excavations 2004, PAM 16, 2004, 429-439; U. WICENCIAK et al., Preliminary Report on a Salvage Campaign at Jiyeh, 2004: The Pottery Production Area, Światowit 46, fasc. A, 2003, 129-133; M. EL TAYEB, Preliminary Report on Salvage Excavations at Jiyeh, 2004: Pottery Production Area B, in: WALISZEWSKI et al. 2006, 40-47; K. DOMŻALSKI, Imported Fine Wares from the Trial Pits B1-3 and Well B4, in: WALISZEWSKI et al. 2006, 48-50; U. WICENCIAK, Coarse Pottery Production at Jiyeh in Sector B1-B3, and Local Coarse Pottery Material from Well B4 at Jiyeh, in: WALISZEWSKI et al. 2006, 54-59, 66.

11 WiCENCIAK, op. cit. (n. 5), 450; D. FRANGIÉ, U. WICENCIAK, Beyrouth et Jiyeh au sein des productions céramiques, Dossiers d'Archéologie 350, 2012, 38-43. On the production of amphorae in Berytus: A. ALA EDDINE, The Development of Beirut Amphorae. A General Approach, in: CH. MORHANGE, M. SAGHIEH-BEYDOUN, La mobilité des paysages portuaires antiques du Liban (BAAL Hors-Série II), Beyrouth 2005, 187-188. On the pottery production centre in Sidon and its affinity with the Jiyeh workshop, see the unpublished doctoral thesis by U. WICENCIAK, Hellenistic and Roman pottery in Phoenicia and the activity of potters' workshop at Jiyeh-Porphyreon (Lebanon) (in Polish), University of Warsaw, 2012.

12 Personal communication from U. Wicenciak.

13 U. WICENCIAK, Local Roman Coarse Ware from Chhim (Southern Lebanon), in: S. MENCHALLI et al. (eds.), LRCW3 Late Roman Coarse Wares, Cooking Wares and Amphorae in the Mediterranean. Archaeology and Archaeometry. Comparison between Western and Eastern Mediterranean, vol. II (BAR International Series 2185), Oxford 2010, 887. 


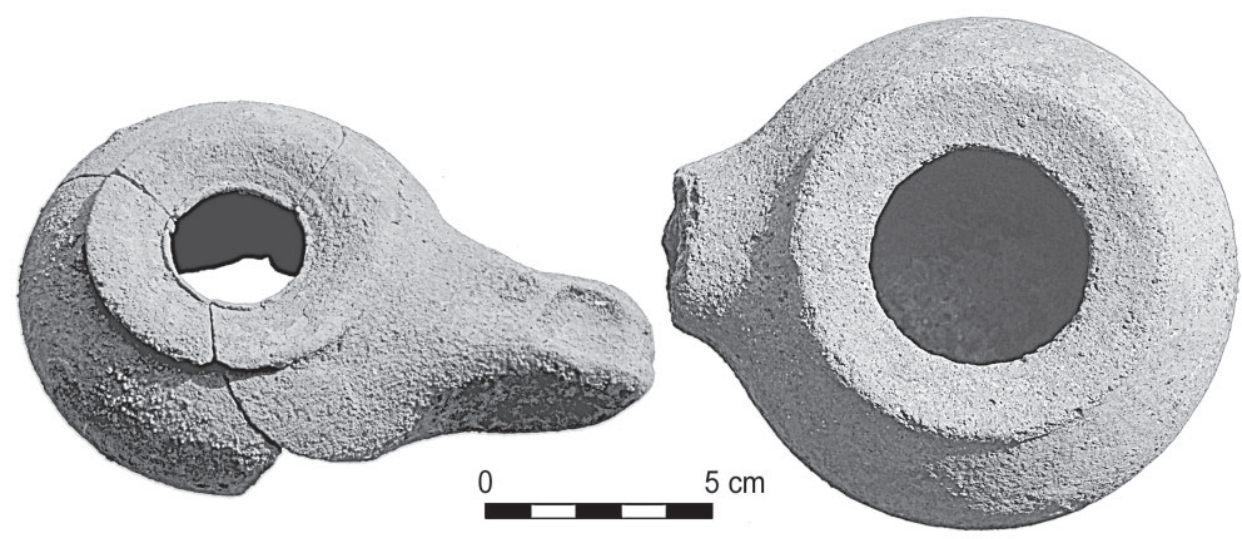

Fig. 4. Hellenistic lamps with an unpierced nozzle (by K. Domżalski)

from the vicinity of Kamid el-Loz in the Beqaa Valley on the eastern side of Mount Lebanon. ${ }^{14}$ After Phoenicia had been conquered by Alexander the Great, this area was controlled by Sidon, ${ }^{15}$ so the distribution of products transported in this type of amphora was generally limited to the territories belonging to Berytus and Sidon.

Moreover, within the section created during construction works between the basilica and the necropolis (Sector C), amphora wasters from the 3rd 4th century were discovered. Additionally, within the same section, an unclear structure erected from mud and rounded in shape (Feature F) was uncovered. It was interpreted by the excavators as a probable pottery kiln. ${ }^{16}$ There is also evidence of amphorae production in Jiyeh in the Early Byzantine period, based on the results of PIXE analyses comparing the fabric of the amphorae from this period with earlier wasters found at the site. ${ }^{17}$

Local production of terracotta oil lamps in the settlement under discussion has been confirmed by the finds of wasters of the so-called watch-shaped lamps with an unpierced nozzle (Fig. 4) dated to the 2 nd and early 1 st century $\mathrm{BC},{ }^{18}$ as well as by much later finds, such as two plaster moulds for

14 A. Ala EdDIne, Hellenistic Stamped Amphorae from Beirut (Site code Bey 004), Archaeology and History in the Lebanon $17,2003,118$.

15 M. SARTRE, D'Alexandre à Zénobie. Histoire du Levant antique, IVe siècle avant J.-C. - IIIe siècle après J.-C., Beyrouth 2001, 148.

16 WiCENCIAK, EL TAYEB, op. cit. (n. 8), 67, 70, fig. 83.

17 M. ROUMIÉ et al., PIXE characterization of Lebanese excavated amphorae from Jiyeh archeological site, Nuclear Instruments and Methods in Physics Research B: Beam Interactions with Materials and Atoms 268(1), 2010, 87-91.

18 DOMŻALSKI et al., op. cit. (n. 10), 433, fig. 7; T. WALISZEWSKI, Lamp-Mould from Jiyeh (Southern Lebanon). A Variant of Ovoid Lamps in the Byzantine and Early Islamic Levant, in: D. FrANGIE, J.-F. SALlES (eds.), Lampes antiques du Bilad es Sham (Jordanie, Syrie, Liban, Palestine). Actes du Colloque de Pétra-Amman (6-13 novembre 2005), Paris 2011, 358.

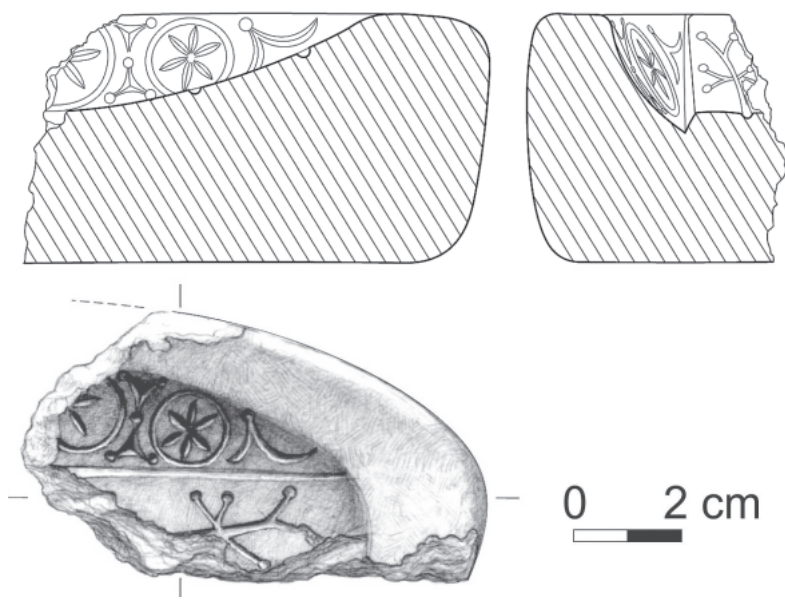

Fig. 5. Early Byzantine lamp mould found in the residential quarter (by M. Puszkarski)

manufacturing the so-called ovoid-type lamps from the 6 th -7 th century. The first mould was discovered in 1975 during R. Saidah's excavations in the residential quarter (Sector D). ${ }^{19}$ The second mould was found in the same area during the Polish-Lebanese excavations in 1997 (Fig. 5), in the fill created during or after the above mentioned Lebanese works. Therefore, both artefacts can be dated only by comparing them with ready-made lamps of this type, found in southern Phoenicia, northern Palestine, Cyprus and Cilicia. ${ }^{20}$

During the clearance of one of the streets within the residential quarter (Sector D) in 2010, several lumps of glass, glass threads and possible wasters were found, which may be evidence of another type of local craft activity - production of glassware. The secondary layer in which these objects were found was probably created by R. Saidah in order to secure

19 SAIDAH, op. cit. (n. 3), 41, fig. 4.

20 WALISZEWSKI, op. cit. (n. 18), 357-359, 365-367. Similar lamps are also known from the neighbouring site in Chhim, cf. ibidem, 371. 


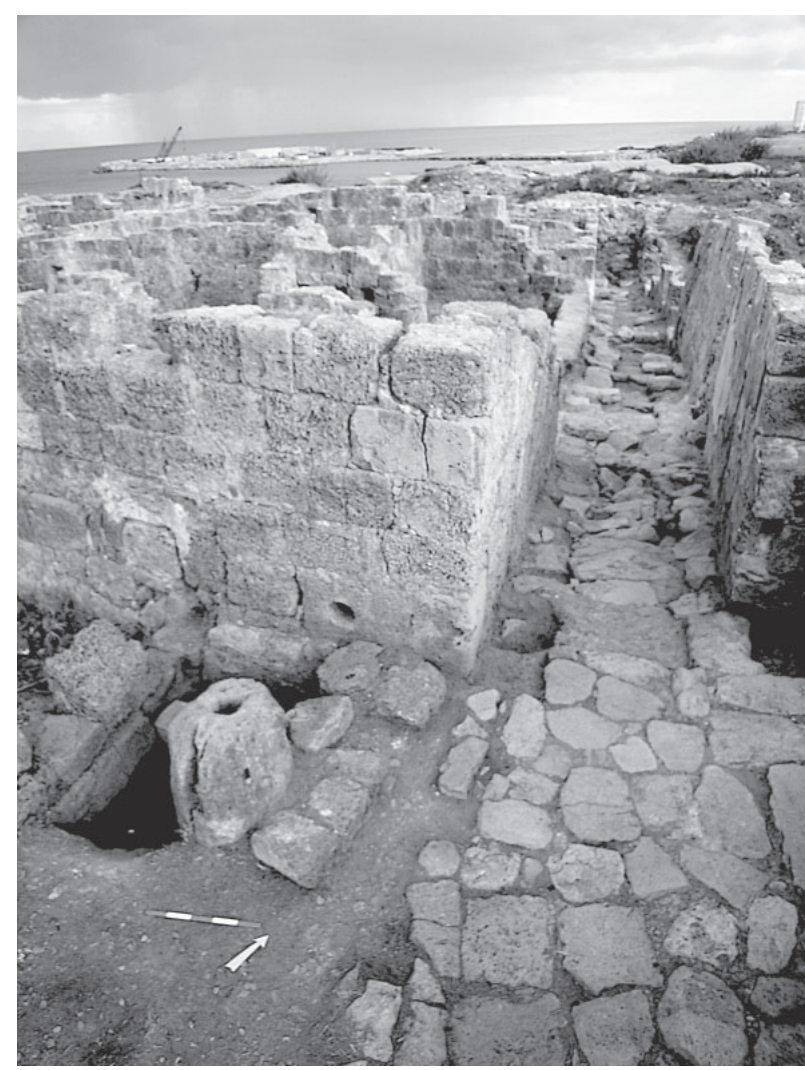

Fig. 6. Counterweight from an olive oil press reused in a house wall (by M. Gwiazda)

the architectural remains after they had been uncovered in 1975. Fragments of glass vessels found together with the lumps and wasters are dated to the 5 th -7 th century, what indicates time of activity of the glass workshop. ${ }^{21}$

The locally manufactured coarse pottery discussed above included transport amphorae which could have been intended for agricultural products from the rural hinterland, such as olive oil, wine, fruits (dates, figs) and fish sauces. The production of olive oil in the investigated settlement in the Roman and Early Byzantine periods is confirmed by the finds of stone elements of presses - especially counterweights with openings in the shape of reversed letter $\mathrm{T}$ and elements of the trapetum (a type of basin for crushing olives). Some of them were found in R. Saidah's fills within the residential quarter (Sector D), therefore their dating is not certain. Another ones were secondarily used as building material in the walls of houses from the 4th century, uncovered in the same sector (Fig. 6). The half-spherical stones with openings, which were originally parts of the trapetum,

21 Information was obtained from M. Wagner who is responsible for publishing glass finds from Jiyeh. On glass production in Berytus, see S. JENNINGS, Vessel Glass from Beirut. BEY 006, 007 and 045, Berytus 48-49, 2004-2005, 287-289.

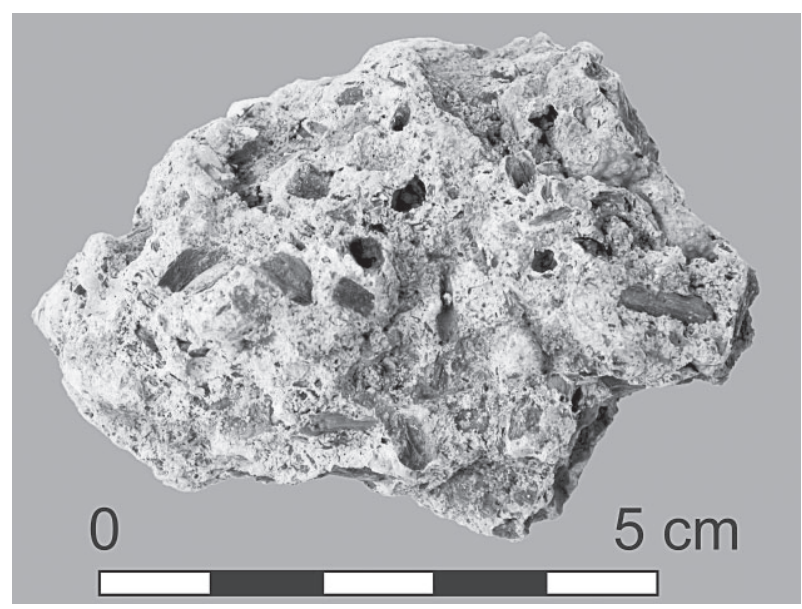

Fig. 7. Mortar sample with burnt olive stones (by M. Gostkowski)

were secondarily used in the 5th or 6th century in the construction of the Christian basilica located nearby. ${ }^{22}$ The stone counterweights with the openings in the shape of reversed letter $\mathrm{T}$ were also found in the area occupied today by the holiday resort (Sector A-B). As they were retrieved during the most recent construction work, there are no indicators as to the exact location of the press or its dating, but their presence may suggest olive oil production in the northern part of the site.

The scale of olive oil production may be to some extent illustrated by archaeobotanical remains. Burnt olive stones are the main part of the botanical material from the layers dated to the Persian, Hellenistic and Roman periods. Moreover, they are the most numerous finds among the archaeobotanical remains from the residential quarter (Sector D) constructed in the 4th century, as well as the Christian basilica dated to the 5th-6th century. Crushed, burnt olive stones, as well as the ash from other plants are, besides the sand, the main admixture to mortar, lime floors, roof tiles and marble revetment binders (Fig. 7). Such an abundance and availability of olive stones can prove constant production of olive oil.

During construction works at the holiday resort (Sector A-B) in 2011-12, a group of collecting vats, probably destined for the grape must, was uncovered. They had been cleared before the arrival of archaeologists, therefore no dating material was found. ${ }^{23}$ The location of these collecting vats next to the workshop which produced transport amphorae

22 T. WALISZEWSKI, Byzantine Basilica $Q$, in: WALISZEWSKI et al. 2006, 30 .

23 This discovery will be the subject of an article in preparation by S. Lenarczyk and Z. Kowarska. 


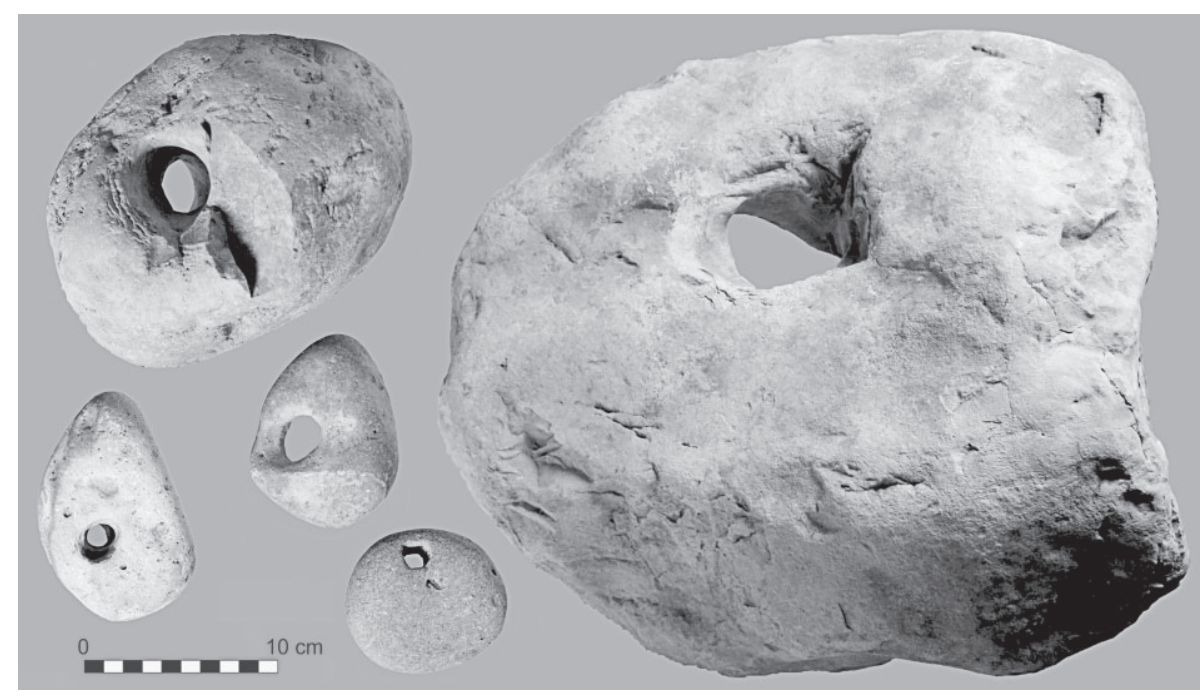

Fig. 8. Selected stone sinkers (by M. Gwiazda)

in the Late Hellenistic and Early Roman periods suggests that they could have been filled with local wine. Pliny the Elder, in his "ranking" of wines, lists, among others, the products from Phoenicia, more specifically from Berytus and Tyre. ${ }^{24}$ The most recent ceramological research indicates that wine from Berytus was poured into the amphorae of the type known from Jiyeh, dated to the 2 nd century $\mathrm{BC}, 25$ but the discovery of the above mentioned vats may suggest that the locally made wine could have been exported as well.

A different branch of the local economy - fishery - is clearly reflected in the archaeological materials by the finds of fish vertebrae, shells of edible molluscs, as well as fishing equipment, including stone and lead net sinkers. The stone sinkers are made of limestone or ramleh (local sandstone). Usually, limestone was used to make smaller sinkers while larger ones were made of sandstone, in which it is much more difficult to drill holes without destroying this brittle material. All discovered stone fishing sinkers can be categorized as undressed ones, with straight perforations for rope (Fig. 8). ${ }^{26}$ They can be divided into two categories: the small ones, weighing 0.1 to $1 \mathrm{~kg}$, and the large ones, weighing 2 to $9 \mathrm{~kg}$. The purpose of the light stone sinkers and the small lead ones (in the form of folded rectangles) was to keep the net in the desired position and shape. They also helped to make the cast net fall down more rapidly,

\footnotetext{
24 Pliny the Elder, Nat. Hist. 14.9.74, 15.18.66-67.

25 WiCENCIAK, op. cit. (n. 5), 450; cf. also C. AUBERT, $A g$ riculture et artisanat en Phénicie héllénistique d'après les fouilles de Beyrouth, Topoi 8, 2007, 8-9.

26 Type S1.2.1, according to E. GALILI, B. ROSEN, J. SHARVIT, Fishing-gear sinkers recovered from an underwater wreckage site, off the Carmel coast, Israel, The International Journal of Nautical Archaeology 31(2), 2002, fig. 2.
}

thus protecting it from tangling. The large stone sinkers were placed at the edges of the net in order to prevent it from drifting. Traps and ropes with hooks may have been also attached to the large sinkers. ${ }^{27}$ The varying weight of the sinkers could have been attributed to different fishing conditions. In the areas where the currents and waves are stronger, heavier sinkers were probably used. In shallow waters with sand bottom beach, seines with sinkers of lower weight could have been used. On the rocky seashore to the west of the settlement it was probably preferred to fish with the use of hooks, also found among the archaeological materials. ${ }^{28}$ Most of the stone net sinkers were found in secondary deposits and therefore they cannot be dated precisely. Parallel finds from Salamina come from the Archaic, Hellenistic and Early Roman layers, but the use of similar objects on the Levantine coast is confirmed for at least as early as the Neolithic. ${ }^{29}$

A considerable importance of fishery in the local economy is proved by production of lead fishing net sinkers. Two moulds for casting such sinkers of the folded rectangular type (Fig. 9) were found in the residential quarter (Sector D), in the secondary layers formed after R. Saidah's excavations in 1975. The first mould, preserved completely, was a $25 \times 9.6 \times 4.5 \mathrm{~cm}$ cuboid. One of its sides featured six recesses and the other side featured nine. The second mould, preserved as a $3.3 \mathrm{~cm}$ thick fragment, has two pairs of decorative recesses rectangular in

\footnotetext{
27 Ibidem, 195-196.

28 Ibidem, 194.

29 M.-J. ChaVANE, Salamine de Chypre VI: Les petits objets, Paris 1975, 111; E. GALILI, O. LERNAU, I. ZOHAR, Fishing and Coastal Adaptations at 'Atlit-Yam. A submerged PPNC Fishing Village off the Carmel Coast, Israel, Atiqot 48, 2004, 21.
} 


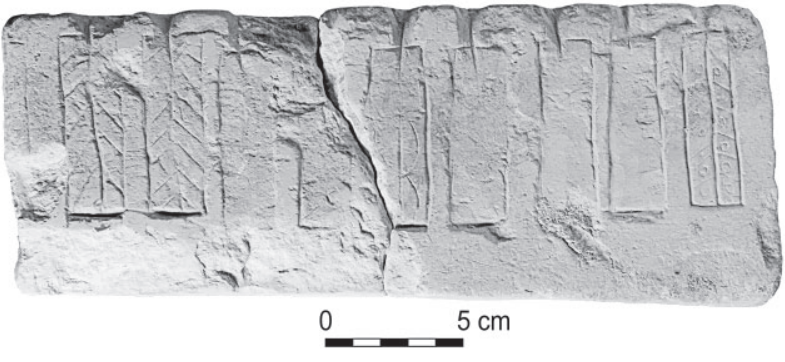

Fig. 9. Mould for fishing net sinkers (by M. Gwiazda)

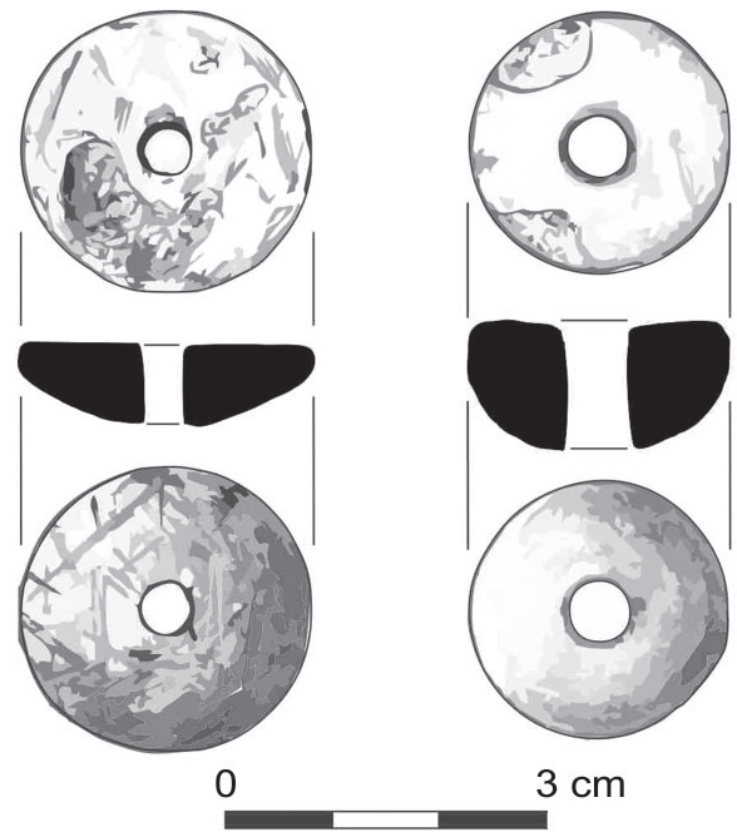

Fig. 10. Selected conical and hemispherical spindle whorls (by M. Gwiazda)

shape on either side. The most common decoration is a motif of lines running perpendicularly to the longer axis of the recesses or in a chevron layout resembling herringbones. Similar moulds are known from other Mediterranean sites. ${ }^{30}$ Despite the fact that no metallurgical furnaces have been discovered so far in Jiyeh, the moulds described above, as well as small amounts of slag found in the Hellenistic, Roman and Early Byzantine layers in several trial pits within the residential quarter (Sector D), confirm the existence of metallurgical workshops in the investigated settlement.

Numerous finds of stone spindle whorls, as well as clay and ceramic loom weights, suggest that spinning and weaving was important element of the

30 Finds from southern Phoenicia: GALILI, ROSEN, SHARVIT, op. cit. (n. 26), fig. 13; from today's Tunisia: M. HARBI-RIAHI, 30 ans au services du patrimoine: de la Carthage des Phéniciens à la Carthage de Bourguiba: 18 octobre 1986 - 18 octobre 1987, année du patrimoine, Tunis 1986, cat. nos. II.38, II.39. local economy. So far, 30 spindle whorls have been found in Jiyeh. They are either hemispherical or conical in shape (Fig. 10) and their weight varies from $3 \mathrm{~g}$ up to $23 \mathrm{~g},{ }^{31}$ which may suggest that weaving threads of different thickness or different fibres, e.g. goat-hair, sheep-hair or linen yarn, were used. ${ }^{32}$ Large share of the goat-sheep bone remains in the archaeozoological materials from the excavations indicates that wool may have been used as well. On the other hand, no traces of flax growing have been found so far. ${ }^{33}$ The spindle whorls were found in the residential quarter (Sector D), in the Christian basilica (Sector Q), and at the necropolis (Sector A), ${ }^{34}$ in layers from the Hellenistic, Roman and Early Byzantine times.

Recorded loom weights can be divided into four types. The most commonly represented (21 finds) is the wheel-shaped type, found exclusively within the Late Hellenistic and Early Roman potters' quarter (Sector B). There is also a widespread occurrence of the doughnut-shaped type (9 items) made of unfired clay, ${ }^{35}$ found only in Persian-Hellenistic layers of the residential quarter (Sector D). The remaining types are: two discoidal loom weights with two perforations and one in the shape of a truncated pyramid (Fig. 11). The diversity of loom weights shapes, as well as their weight and thickness, may suggest

31 Minimum spindle whorl weight for spinning threads is $4 \mathrm{~g}$; cf. L. MÅRTENSSON et al., Technical Report. Experimental Archaeology, Part 2: 2: Whorl or bead? 2006. Tools and Textiles - Texts and Contexts, Research Program. Danish National Research Foundation's Centre for Textile Research, University of Copenhagen, available online at http://ctr.hum.ku.dk/tools/. Spindle whorls weighing less could be used as additional load for the spindle.

32 Cf. E. J.W. BARBer, Prehistoric Textiles. The Development of Cloth in the Neolithic and Bronze Ages with Special Reference to the Aegean, Princeton 1992, 52.

33 The production of linen fabrics in Byblos is attested in Diocletian's Edict (Edictum Diocletiani de Pretiis Rerum Venalium 26-28). For written sources on production and trade of linen textiles in Berytus and Tyre, see L. JONES HALL, Roman Berytus. Beirut in Late Antiquity, London-New York 2004, $26-27,223$

34 Similar discovery was made in nearby Chhim, where in one of the loculi of an Early Byzantine tomb five stone spindle whorls were found, lying next to the upper and lower part of the body; R. ORTAli-TARAZI, B. StUART, Two Rock-Cut Roman Tombs in Chhim, BAAL 6, 2002, 124.

35 Discoid and truncated pyramid-shaped loom weights with two perforations, made of unfired clay, are known from Beirut, Sarepta and Sidon: J. ELAYI, H. SAYEGH, Un quartier du port phénicien de Beyrouth au FER III/Perse. Les objets (Transeuphratène, supplément 6), Paris 1998, 233, cat. no. 3; AUBERT, op. cit. (n. 25), 15; J.B. PRITCHARD, Sarepta IV. The objects from Area II, X. The University Museum of the University of Pennsylvania Excavations at Sarafand, Lebanon, Beyrouth 1988, 99, cat. nos 10-11; G. CONTENAU, Mission archéologique à Sidon (1914): deuxième partie, Syria 1, 1920, 109. 
different cultural influences and/or production of various fabric types. ${ }^{36}$ To sum up, all these finds come from layers dated up to the Early Roman period. The lack of loom weights in the Early Byzantine contexts and the incessant use of spindle whorls in that period should be attributed to the resignation from warp-weighted looms and the substitution of those with two beam or horizontal looms which did not require the use of loom weights. ${ }^{37}$

The toponym "Porphyreon," first used by PseudoScylax as a name for the investigated settlement, may suggest the production of purple in this area. ${ }^{38} \mathrm{It}$ was manufactured from sea snails - murexes. Although single murex shells occurred in the Persian and Hellenistic layers in the test trenches within the residential quarter (Sector D) (Fig. 12), no concentrations of such shells have been found to date in any part of the site. This can be explained by the fact that due to the unpleasant smell connected with the production of the purple dye, the possible workshop would be located away from the settlement, in the areas occupied today by various buildings. ${ }^{39}$

At least since the 4th century lime was produced in Jiyeh on a large scale for construction purposes. It was used to make mortar, wall plaster and floors. In 2012, in one of the rooms cleaned in the southeastern part of the residential quarter (Sector D), a storing area for lime was discovered (Fig. 13). On a beaten floor of the room a layer of pure lime was deposited, reaching a height of $60 \mathrm{~cm}$. The room was explored by R. Saidah in 1975, who removed a part of the lime filling, and afterwards this structure was partly destroyed and covered with a layer of rubble and sand. However, in the remaining lime layer a coin dated to the 4th century was found. For earlier periods there is weak evidence of its use, with

36 Cf. L. MÅrTENSSON, M.-L. NOSCH, E. ANDERSSON STRAND, Shape of Things: Understanding a Loom Weight, OJA 28(4), 2009, 373-398.

37 Similar results were obtained in Chhim where 25 spindle whorls and no loom weights were found in the Roman and Early Byzantine contexts. On the introduction of new types of looms in the Roman period, see J.P. WILD, The Roman Horizontal Loom, AJA 91(3), 1987, 459-471; G.R. DAVIDSON, D. BURR ThOMPson, H. THOMPSON, Small Objects from Pnyx: I (Hesperia Supplements, vol. 7), Amsterdam 1975 (Reprint), 70-71.

38 PSEUDO-SCYlaX, Periplus 104. Later this toponym is mentioned by POLYBIUS (Hist. V.68) and PILGRIM OF BorDEAUX (Itinerarium Burdigalense 18,21).

39 JULIAN OF ASCALON (14) recommends that due to the unpleasant smell, cheese and fish sauce manufactures should be located at a distance from settlements. On the other hand, STRABO (Geogr. 16.2.23) informs that in Tyre the production of purple was based in the city itself. Cf. also K. GRATTON, Production et échange de la pourpre au Proche-Orient aux époques grecque et romaine, Topoi, Suppl. 8, 2007, 151-172; D. S. REESE, Shells from Sarepta (Lebanon) and East Mediterranean Purple-Dye Production, MAA 10(1), 2010, 113-141.
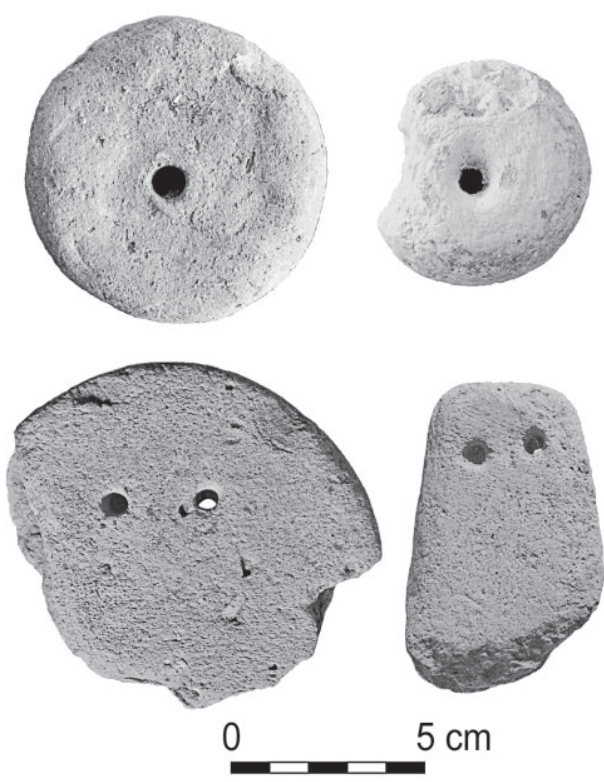

Fig. 11. Selected loom weights (by M. Gwiazda)

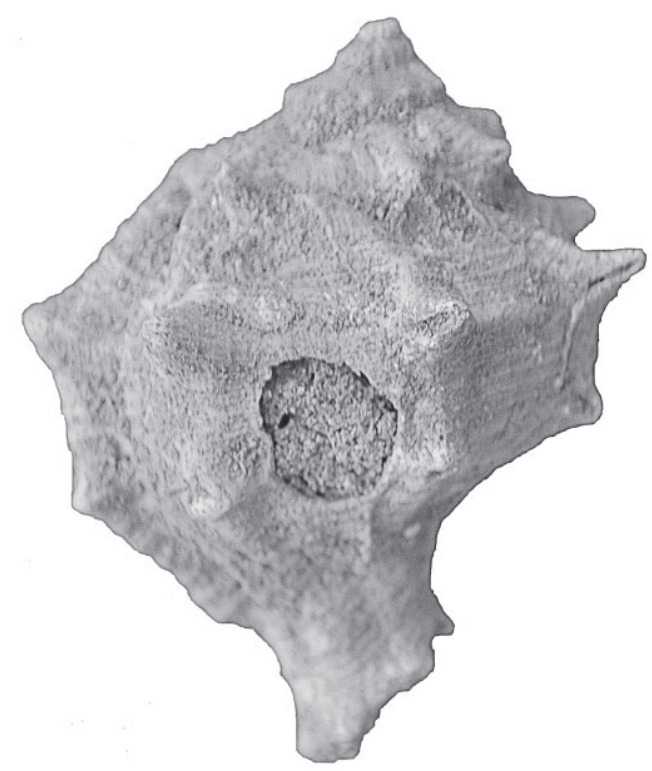

Fig. 12. Murex trunculus from the residential quarter (by A. Romaniuk)

the exception of the so-called potters' quarter (Sector A), where basins made with the use of lime mortar were found. ${ }^{40}$ In the closest vicinity, sandstone is predominant, so the raw material was probably transported from the lower parts of the mountainside, to the east and south of the site. ${ }^{41}$ Limestone blocks were also used rarely for other purposes, as for making thresholds.

40 EL TAYEB, op. cit. (n. 10), 45.

41 The exploitation of limestone continues today by a cement factory located at an altitude of ca. $230 \mathrm{~m}$ a.s.1., $4 \mathrm{~km}$ to the south of Jiyeh. 


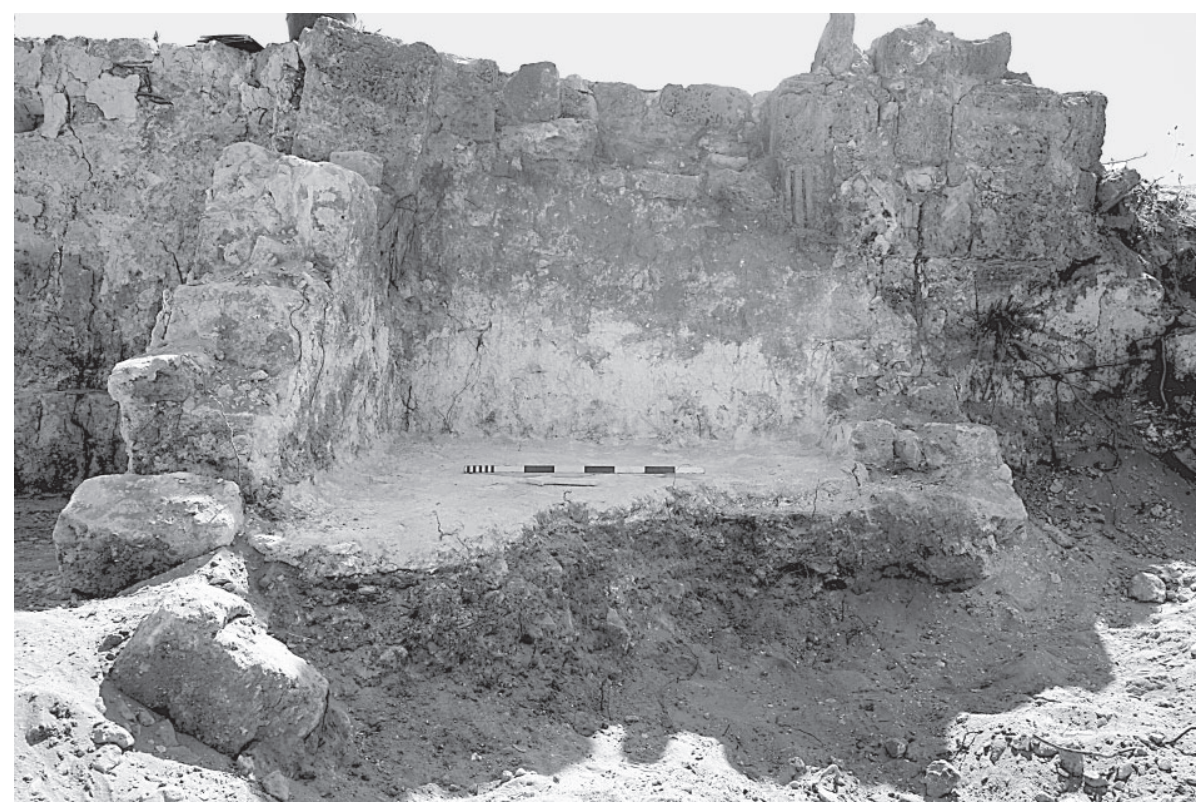

Fig. 13. Room used for storing lime (after cleaning). White traces of lime deposit seen on the walls (by M. Romaniuk)
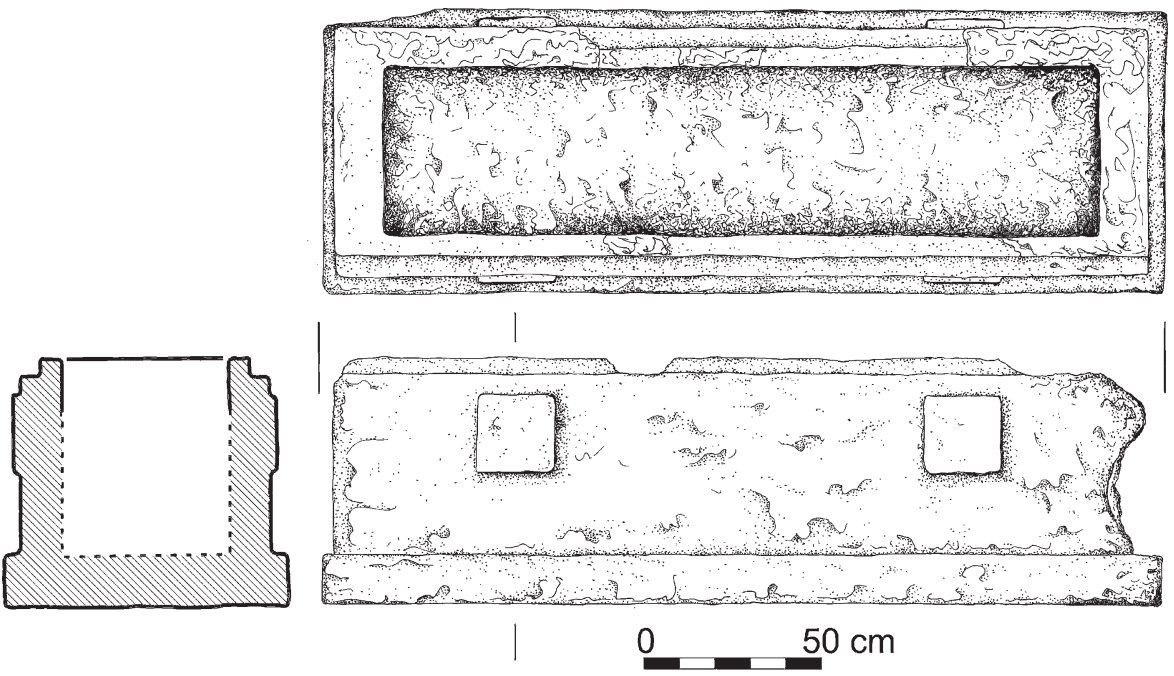

Fig. 14. Locally made sandstone sarcophagus found in the necropolis (by M. Makowska)

Sarcophagi, stelae and cippi carved in the local sandstone (ramleh) are remains of another craft. In most cases they were removed from their original contexts by modern construction works within the area of the necropolis (Sector A). The sandstone sarcophagi are undecorated, or the ornaments are limited to two round or square bosses on the longer sides (Fig. 14). Their lids are flat or have the form of gables with acroteria at four angles. Sarcophagi, stelae and cippi from Jiyeh are very similar to the Hellenistic and Early Roman ones found in Sidon, what may indicate that the craftsmen from the former settlement imitated products from Sidon or that some mobile sculptors' workshops operated in this area. ${ }^{42}$ However, an important difference is that the funeral objects from Jiyeh had no inscriptions,

42 For limestone sarcophagi found near Sidon, see G. CONTENAU, Mission archéologique à Sidon (1914). Troisième article. La caverne aux inscriptions, Syria 1, 1920, 213-214, fig. 73; IDEM, op. cit. (n. 35), 150-151, fig. 49, cf. E. RENAN, Mission de Phénicie, Paris 1864, 505. For cippi and stelae, see ibidem, 381382; TH. MACRIDY, Le temple d'Echmoun à Sidon, Revue Biblique 1, 1914, 391-392, 398, 401-402, 547-556, figs. 30, 35, pl. XII.2-4; G. CONTENAU, Mission archéologique à Sidon (1914). Quatrième partie. Les cippes, Syria 1, 1920, 287-289; IDEM, Deuxième mission archéologique à Sidon (1920), Syria 4(4), 1923, 266; M. MEURDAC, L. ALBANÈSE, A travers les nécropoles gréco-romaines de Sidon (suite), BMB 3, 1939, 50-51, pl. VIII. 
which can suggest that the inhabitants were illiterate to a larger extent than Sidonians.

Apart from the craft and agriculture production, trade played an important role in the local economy, too. The archaeological evidence of trade exchange includes measuring devices as well as imported goods. Weights and measures were made of bronze, lead and stone. Forms of the metal weights found in Jiyeh are typical of Hellenistic, Roman and Early Byzantine Syro-Palestine. The shape of a large, almost completely preserved, marble cuboid-shaped weight with two hemispheres is unique in the Levant (Fig. 15). Its dimensions are $18.4 \times 9.9 \times 7.5 \mathrm{~cm}$. At present it weighs $2,506 \mathrm{~g}$, which indicates that the original weight was probably 8 librae (ca. 2,616 g). Such weights are well known from Greece where they occur most of all in Roman and Early Byzantine contexts. ${ }^{43}$ This may indicate the dating of the described weight, found in a modern fill in the residential quarter (Sector D). Moreover, four marble measures with rounded hollows were also discovered there during R. Saidah's and Polish-Lebanese excavations (Fig. 16). ${ }^{44}$

Other objects which provide evidence for the longdistance trade exchange are imports of ceramics and marbles. Hellenistic and Early Roman fine wares recorded in Jiyeh came from several production centres: colour-coated ware from the south-eastern Aegean and the Levant, black-gloss ware from western Italy and Asia Minor, Eastern Sigillata A from the area between Antiochia-on-the-Orontes and Tarsus, the so-called Cypriot Sigillata most probably from southern Asia Minor, as well as small amounts of South Gaulish Sigillata and early vessels of African Red Slip Ware produced in the area of today's Tunisia. The Early Byzantine period is represented by the continued imports of African Red Slip Ware, as well as Late Roman C/Phocean Red Slip Ware from the eastern Aegean, the so-called Cypriot Red Slip Ware from southern Asia Minor, and small amounts of Egyptian Red Slip Ware. More information on maritime trade connections will be provided by a detailed analysis of amphorae which is, however, still in progress.

43 Delos: W. DEONNA, Exploration archéologique de Délos, Tome 18.1, Le mobilier délien, Paris 1938, 144-145; Corinth: G. DAVIDSON, Corinth, Volume 12, The Minor Objects, Princeton 1952, 205-206, 213-214, pl. 97; cf. also M. LANG, M. CROSBY, The Athenian Agora, Volume X, Weights, Measures and Tokens, Princeton 1964, 34-38. For Levantine finds, see M. CHÉHAB, Mosaïques du Liban: Texte, BMB 14, 1957; IDEM, Mosaïques du Liban: Planches, BMB 15, 1959, pl. XC.1; F. TURQUETY-PARISET, Fouilles à la municipalité de Beyrouth (1977), Syria 59(1-2), 1982, 53, fig. 15; RENAN, op. cit. (n. 42), 29, 849, pl. XII.2.

44 For the same type found in Beirut, see TURQUETY-PARISET, op. cit. (n. 43), 53, fig. 15. Cf. also DEONNA, op. cit. (n. 43), 167-175.

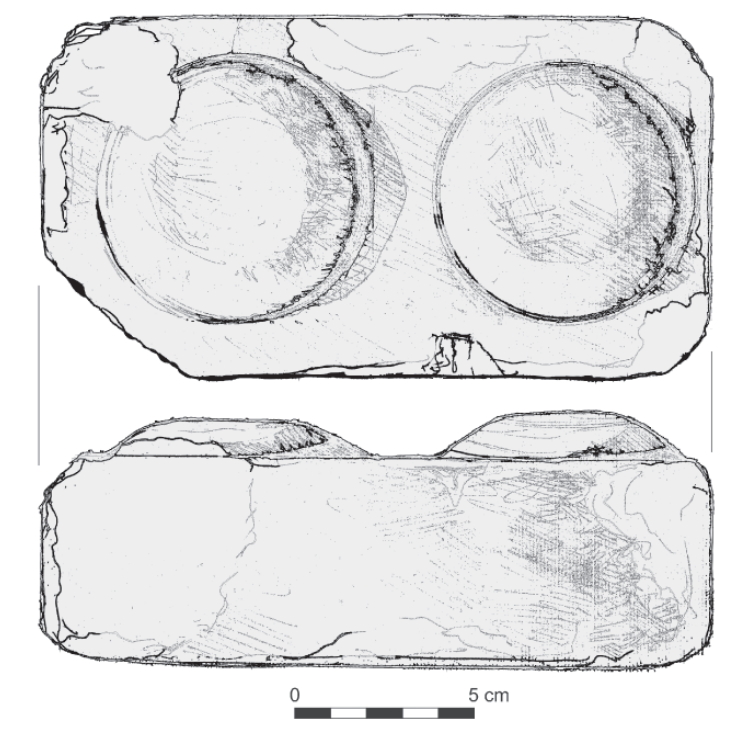

Fig. 15. Marble weight (by M. Puszkarski, M. Gwiazda)

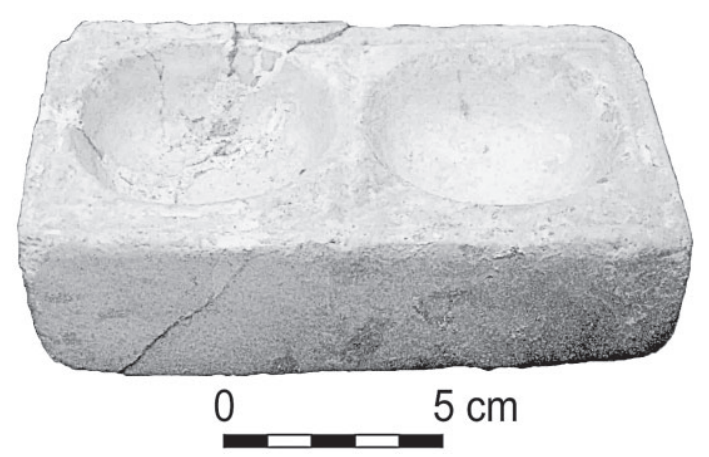

Fig. 16. Marble measure (by K. Kotlewski)

With the construction of the Christian basilica in the 5th or 6th century a demand appeared for large quantities of building materials which were unavailable locally, including white and coloured marbles that were used for finishing this most prominent building. The imported stone was used for making wall decorations in the presbytery, the column shafts and capitals, and probably for finishing floors. A part of the liturgical equipment was also made of marble. Several marble objects have been found recently in the basilica during the Polish-Lebanese excavations. However, the layers they came from were formed secondarily after 1988, when the floor mosaics were removed from the basilica and transported to the museum in Beit ed-Dine.

Marble objects were also found in the residential quarter (Sector D), in the secondary layers formed after R. Saidah's excavations had been finished. As there is no architectural evidence that marble was used for finishing these houses, the objects may have been originally found in the basilica as well. Marble wall decorations are indicated there by the regularly arranged little holes for hooks in the eastern 


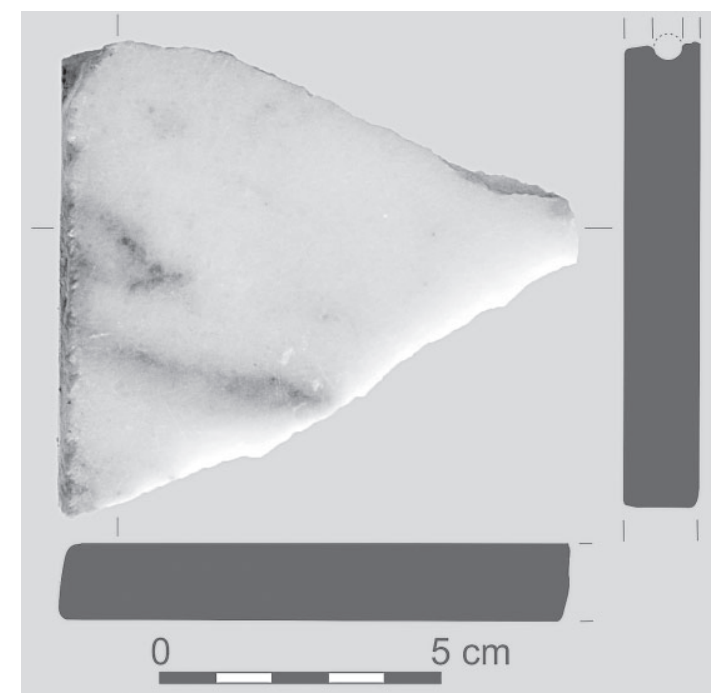

Fig. 17. Crusta from the Christian basilica (by M. Gwiazda)

wall. ${ }^{45}$ Some of the holes are covered with greenish corrosion, left by the copper alloy hooks to which marble tiles were attached (Fig. 17). Most of the marble tiles $(1-2 \mathrm{~cm}$ thick) are covered with ash mortar, visible also on the walls of the basilica's presbytery.

Two-thirds of the marble crustae are made of white, coarse-grained marble with blue veins, typical of materials from the quarries in Proconnesus. Some tiles were made of grey marble of uncertain origin (grey Proconnesian marble?). Moreover, crustae and opus sectile tiles found in Jiyeh were also made of the following stones: breccia coralina (Bithynia), cipollino verde (Euboea), giallo antico (Chemtou, today's Tunisia), pavonazetto (Phrygia), serpentino verde (Laconia), and verde antico (Thessaly) (Fig. 18). Yet, they were found in much smaller quantities. The pro- minent role of the Proconnesian marble is illustrated by other architectural elements as well, mainly columns. Several column fragments were discovered during the excavations. Two large column fragments and a Corinthian capital, probably coming from the basilica, are currently located in the nearby mosque where they were secondarily used as support in the main hall. ${ }^{46}$

Various white marbles were used to make elements of the church liturgical equipment, such as the socalled polylobed sigma table, chancel screens and

45 Cf. T. WALISZEWSKI, Byzantine Basilica $Q$, in: WALISZEWSKI et al. 2006, fig. 38 (drawing of the view of the eastern basilica wall with marked openings for the wall facings).

46 Cf. S. Garreau Forrest, Pérennité de l'occupation des sites sacrés de l'Antiquité à l'époque moderne, Dossiers d'Archéologie $350,2012,58-59$. One of the capitals from the basilica was published by CONTENAU, Mission.... Quatrième partie (n. 42), 296, fig. 92 chancel posts, the mensa, small columns under the altar, and à bec de corbin-type plates (Fig. 19). All these objects are very similar in form to those found in other contemporary churches in Syro-Palestine, including the nearby located church in Chhim where, however, the use of imported stones is limited exclusively to the liturgical equipment. ${ }^{47}$

The last category of objects indicating long-distance trade exchange are roof tiles. At least two types of roof tile were identified in Jiyeh. The first one has yellow fabric, a finer texture and the shape of a Corinthian imbrex, while the other one has red fabric, coarse texture and the shape of a Sicilian imbrex. No evidence of roof tile production has been found to date in Jiyeh and the fact that both fabrics are clearly different from that of the locally manufactured pottery indicates that they were imported. ${ }^{48}$ The vast majority of roof tiles found in the layers secondarily formed in the last decades (Sectors Q and D) had most probably originally covered the roof of the Early Byzantine basilica. ${ }^{49}$ All of them seem to be well selected, with no badly fired pieces or accidental imprints. The yellow tiles (type 1) show some similarity to the contemporary tiles from Cyprus. ${ }^{50}$ However, it is impossible to determine whether they were imported from the island or from a different source.

To sum up, the archaeological evidence gathered to date gives us a general picture of the economy of the investigated settlement from the Hellenistic through the Early Byzantine period. Although it is difficult to determine to what extent it was self-sufficient in the agricultural production, as we know nothing about grain and vegetables cultivated in this area, we do have abundant evidence of olive oil and wine production. More coherent is the outlook on the crafts. The local production of ceramic vessels for the inhabitants' daily needs, including amphorae for storage and transport of agricultural products and

47 I wish to express my gratitude to D. Wielgosz for her help in identifying the marbles from Jiyeh and Chhim.

48 Both types of roof tiles were found in Chhim as well. Chemical analyses and thin sections of these finds have shown that they were produced outside Phoenicia; M. DASZKIEWICZ, G. SCHNEIDER, E. BOBRYK, Pottery from Chhim - preliminary results of archeometric analysis (unpublished).

49 Roofs of traditional and modern houses in Jiyeh and Chhim are flat and there is no evidence that in Antiquity they were constructed in a different way. Only in higher parts of Mount Lebanon, where the rainfall and snowfall are stronger, buildings have sloping roofs covered with roof tiles.

50 M. RaUtman, Neutron Activation Analysis of Cypriot and Related Ceramics at the University of Missouri, in: H. MEYZA, J. MŁYNARCZYK (eds.), Hellenistic and Roman Pottery in the Eastern Mediterranean - Advances in Scientific Studies. Acts of the IInd Nieborów Pottery Workshop. Nieborów, 18 - 20 December 1993, Warszawa 1995, 333-336, pl. 8.40. 


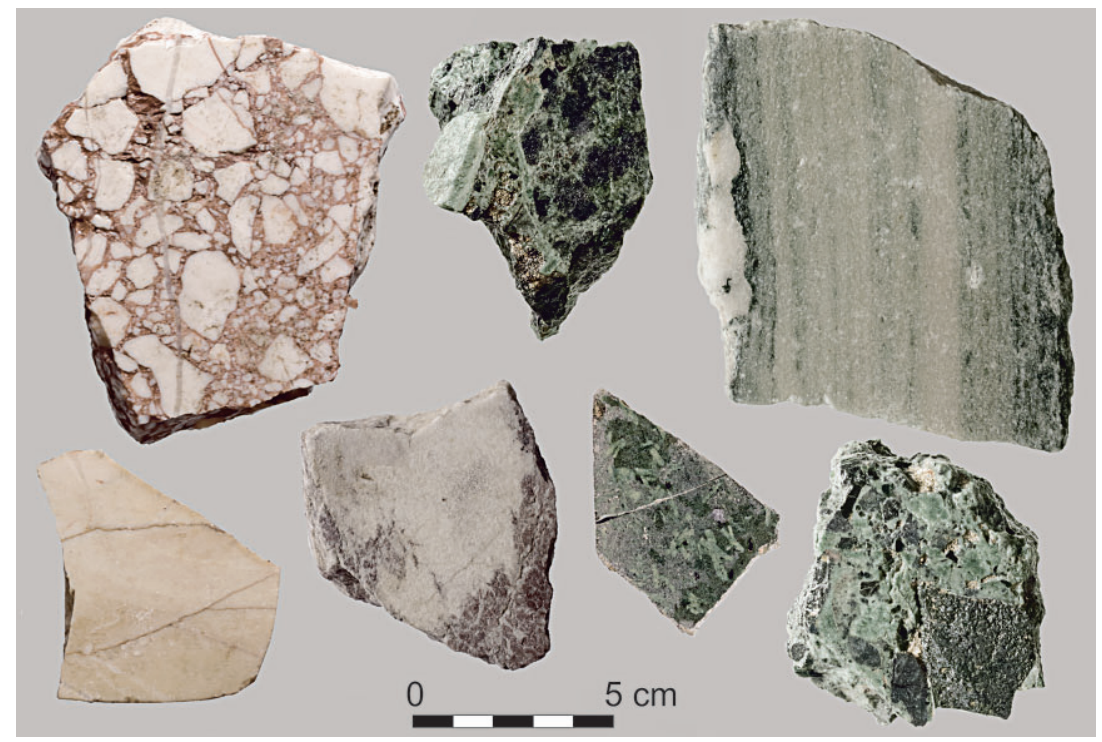

Fig. 18. Selection of colour marbles (by M. Gwiazda)

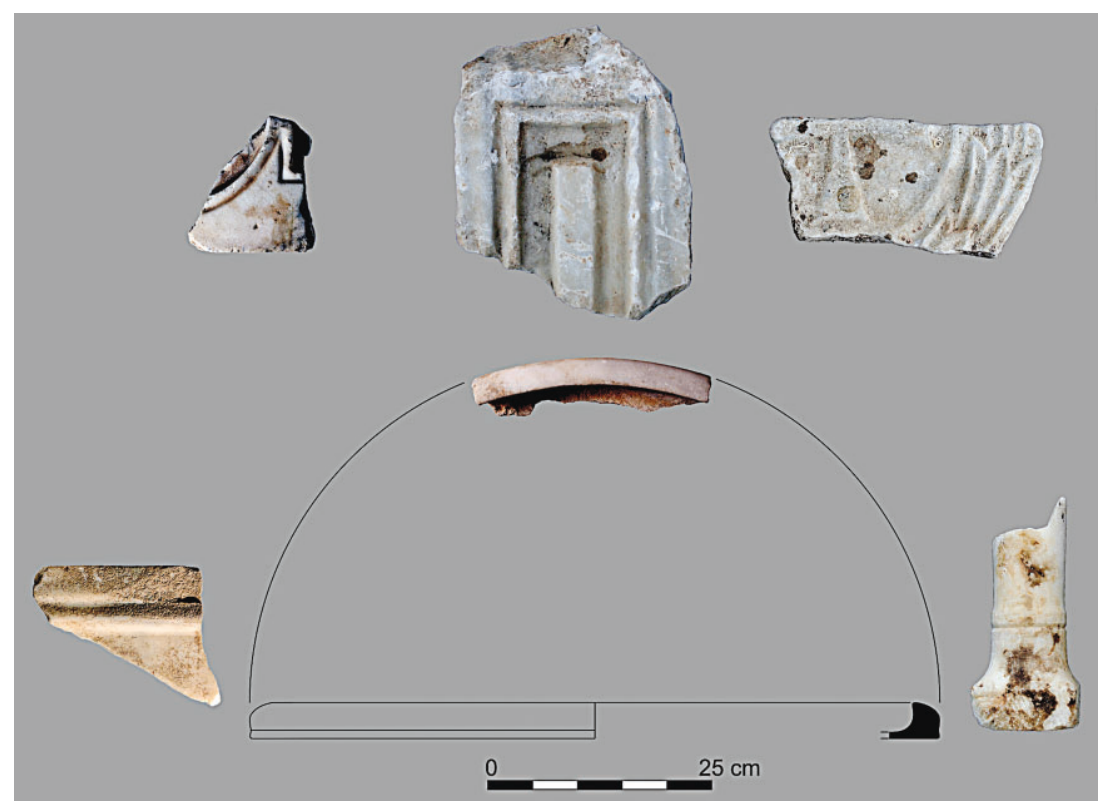

Fig. 19. Selection of marble liturgical equipment: polylobed sigma table, chancel post and screen, mensa, à bec de corbin-type plate, altar column (by M. Gwiazda)

terracotta lamps, is attested for the whole period under discussion. It is possible that some of these wares, ${ }^{51}$ as well as a surplus of the olive oil and wine production, were sold to neighbouring settlements, bringing an additional income.

Another activity taken up by the inhabitants was fishing and collecting of the molluscs. It is proved by both archaeozoological finds and elements of fishing equipment. Moreover, finds of slag and moulds

${ }^{51}$ E.g., no Hellenistic and Roman amphorae produced in Jiyeh were found so far in Chhim, in contrary to the later products, recorded there in large quantities; cf. WICENCIAK, op. cit. (n. 13), 887. for net sinkers confirm the local production of metal goods, which was probably limited to the needs of the settlement. Concerning spinning and weaving, this craft was possibly particularly developed, being also connected with dying fabrics with purple. It is indicated by the diversity of the equipment for thread and textile production. The lack of loom weights in the Early Byzantine contexts in which the spindle whorls are still present may indicate a fast introduction of horizontal looms in the local workshops.

Stone-work and constructing activity was developed in Jiyeh between the Hellenistic and the Early Byzantine period. Although sandstone was the easiest available material, the local craftsmen used also the nearby located resources of limestone for the 
production of mortars, plasters and architectural elements, such as thresholds. Moreover, stone was widely used for sepulchral purposes, as shown by sarcophagi, stelae and cippi, made in the style known from Sidon and its vicinity.

According to the picture presented above, some economic activities in the investigated settlement certainly generated surpluses, which enabled the inhabitants to purchase imported products. It is best exemplified by the constant influx of ceramic tableware from distant production centres. Some of these goods were subsequently distributed to the neighbouring villages. The available evidence shows that the peak of the economic growth probably took place in the Early Byzantine period when a residential quarter was built, together with the large Christian basilica embellished with imported marble and roof tiles. A similar peak of prosperity in the same period was noted in the settlement of Kopetra, located near the southern coast of Cyprus, ${ }^{52}$ as well as in various parts of Syro-Palestine. ${ }^{53}$ According to the archaeologists working in Kopetra, the settlement played an important role as a subregional economic link, connecting mountain villages specialized in agricultural production and copper mining with the maritime trade network providing imported goods. The same can be said about the investigated settlement in Jiyeh.

Remains of olive oil and wine presses found in the mountain villages located to the east of Jiyeh, especially in Chhim, indicate a high level of agricultural production in this microregion. ${ }^{54}$ These villages must have had surpluses exchanged for imported goods, such as imported fine pottery, marbles and roof tiles. All these imports are characterized by a lesser diversity of forms than the parallel finds from Jiyeh, and they come from a smaller number of production and mining centres. This confirms an intermediary role of the ancient settlement in Jiyeh, located directly at the coastline ${ }^{55}$ and on the principal route of the via maris, in the trade exchange between the off-coast areas of this microregion and other parts of Phoenicia and the entire Mediterranean world.

Polish-Lebanese excavations of the settlement in Jiyeh are still in progress, as is also surveying of its neighbourhood and analyzing of the archaeological materials. Therefore, the tentative conclusions presented above, shedding important light on the economy of Phoenician countryside from the Hellenistic through the Early Byzantine period, should be complemented in the future, especially by results of detailed archaeobotanical and archaeozoological analyses showing the scale of grain, vegetable and animal farming. Further discoveries may also help to fill in some gaps in our knowledge of the chronology and scale of local crafts.

Ośrodek Badań nad Antykiem

Europy Południowo-Wschodniej

Uniwersytetu Warszawskiego

Krakowskie Przedmieście 32

PL - 00-325 Warszawa

mariusz.gwiazda@gmail.com

\section{ABBREVIATIONS}

BAAL - Bulletin d'Archeologie et d'Architecture Libanaises BMB - Bulletin du Musée de Beyrouth

MAA - Mediterranean Archaeology and Archaeometry

OJA - Oxford Journal of Archaeology

OLA - Orientalia Lovaniensia Analecta
WALISZEWSKI et al. 2002 - T. WALISZEWSKI et al., Village romain et byzantin à Chhîm-Mariyat. Rapport préliminaire (1996-2002), BAAL 6, 2002, 5-105;

WALISZEWSKI et al. 2006 - T. WALISZEWSKI et al., Jiyeh (Porphyreon) Hellenistic, Roman and Byzantine settlement on the southern coast of Lebanon. Preliminary report on the 1997 and 2003-2005 seasons, BAAL 10, 2006, $5-84$.

Y. HIRSCHFELD, Settlement of the Negev in the Byzantine Period in Light of the Survey at Horvat Sa'adon, Bulletin of the Anglo-Israel Archaeological Society 24, 2006, 7-49.

54 M. EL TAYEB, Archaeological Reconnaissance in Iqlim el Kharoub, Preliminary Report, in: WALISZEWSKI et al. 2002, 10-11; WALISZEWSKI et al. 2002, 20-28.

55 So far, there is no evidence of an ancient harbour in Jiyeh. The modern harbour is located in a bay to the southwest of the site. The bay itself protects this part of the coastline from southern winds. According to PolYBIUS (Hist. V.68), the Ptolemaic fleet was anchored there during the battle with the army of Antioch III in $218 \mathrm{BC}$; cf. also M. WOŹNIAK, Strategy and the Use of Terrain in the Battle of Porphyreon, 218 BC, in: WALISZEWSKI et al. 2006, 9-12. 